\title{
sciendo
}

CIVIL AND ENVIRONMENTAL ENGINEERING REPORTS

E-ISSN 2450-8594

CEER 2021; 31 (3): 0251-0264

DOI: $10.2478 /$ ceer-2021-0044

Original Research Article

\section{EFFECTIVENESS OF POLLUTANT REMOVAL AT THE WASTWEWATER TREATMENT PLANT IN GOLENIÓW}

\author{
Anita JAKUBASZEK ${ }^{1}$ \\ University of Zielona Góra, Zielona Góra, Poland
}

\begin{abstract}
The article assesses the efficiency of pollutant removal at the sewage treatment plant in Goleniów after modernization of the technological system. The extension and modernization of the existing installation resulted from the need to adapt the treatment plant to accept larger loads of pollutants, improve the parameters of treated sewage discharged to the receiver, and the poor technical condition of the equipment. Before the modernization of the treatment plant, an increase in the loads of $\mathrm{COD}, \mathrm{BOD}_{5}$, and periodic total suspended solids in raw sewage was observed as well as a reduction in the efficiency of removing pollutants from the sewage. The efficiency of removing pollutants after modernization was in the range of $\mathrm{BOD}_{5}-94.4 \div 99.8 \%$, COD $-89.3 \div 98.9 \%$, total suspended solids TSS $-95.3 \div 99.7 \%$, total nitrogen $-64.1 \div 95.4 \%$, and total phosphorus $-75.4 \div 99.4 \%$.
\end{abstract}

Keywords: wastewater treatment, modernization, wastewater treatment plant

\section{INTRODUCTION}

The composition of wastewater is one of the basic criteria for the selection and modernization of the sewage treatment technological system. It is diverse, variable over time and depends on many factors, including the nature and size of

\footnotetext{
${ }^{1}$ Corresponding author: University of Zielona Gora, Faculty of Building, Architecture and Environmental Engineering, Institute of Environmental Engineering, Z. Szafrana st 15, 65-516 Zielona Góra, Poland, e-mail: A.Jakubaszek@iis.uz.zgora.pl
} 
agglomeration and the share of industrial wastewater [2,3]. Domestic wastewater contains about $60 \%$ of various types of organic substances dispersed in the water, and about $40 \%$ of inorganic substances, including human and animal excreta (urine and feces), food residues and waste, sand, soaps and other washing agents (detergents), and paper. The effectiveness of technological processes is mainly determined by the content of biodegradable substances [7]. In the case of modernization of sewage treatment plants, it is important to analyze archival data, and at the same time, to prepare a forecast on the quantity and quality of sewage and planned changes in the development of the agglomeration[1, 4-6].

The article assesses the efficiency of removing pollutants at the sewage treatment plant in Goleniów after the modernization of the technological system. The expansion and modernization of the treatment plant were necessary due to the increasing loads of pollutants in the wastewater flowing into the treatment plant. This was caused by the expansion of the sanitary sewage system and the connection of the Goleniów Industrial Park to the wastewater treatment plant.

\section{RESEARCH OBJECT}

The mechanical and biological wastewater treatment plant in Goleniów (view of the treatment plant in Fig. 1), with an average capacity of Qd $-8,190 \mathrm{~m}^{3} /$ day, works based on the technology of low-loaded activated sludge, with oxygen stabilization of the sludge and chemical phosphorus precipitation.

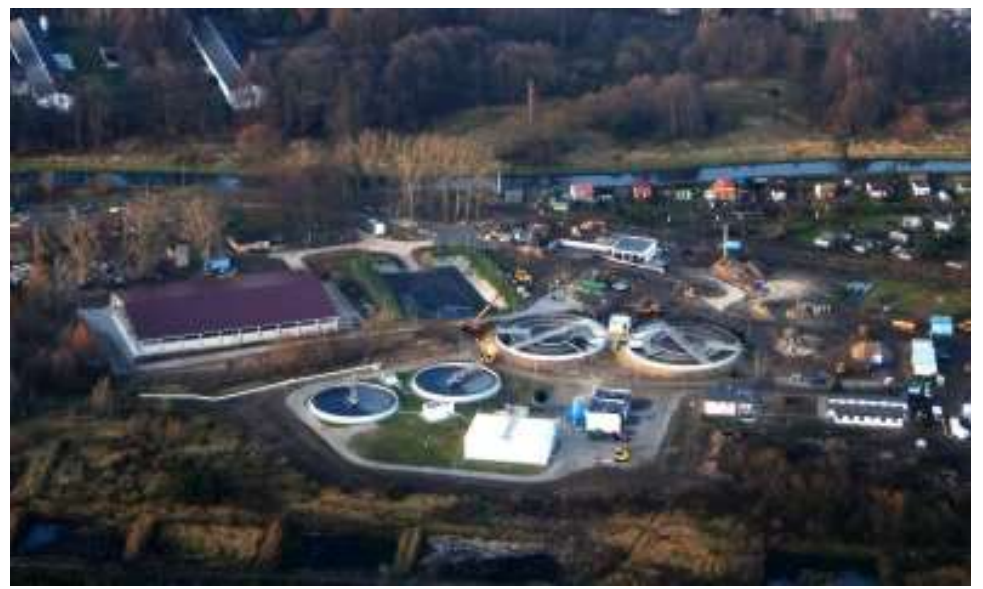

Fig. 1. Wastewater treatment plant in Goleniów

For the Goleniów agglomeration, with an equivalent population of 57,063 PE, Annex 3 to the Regulation of the Minister of Maritime Economy and Inland 
Navigation applies, in which the maximum concentrations of pollutants in the wastewater discharged to the receiver are respectively [8]:

\begin{tabular}{|c|c|}
\hline $\begin{array}{l}\mathrm{BOD}_{5}-25 \mathrm{mg} \mathrm{O} / \mathrm{dm}^{3} \\
\text { COD }-125 \mathrm{mg} \mathrm{O}{ }_{2} / \mathrm{dm}^{3} \\
\text { TSS - } 35 \mathrm{mg} / \mathrm{dm}^{3} \\
\text { Total nitrogen }-15 \mathrm{mg} \mathrm{N} / \mathrm{dm}^{3} \\
\text { Total phosphorus }-2 \mathrm{mg} \mathrm{P} / \mathrm{dm}^{3}\end{array}$ & $\begin{array}{l}\text { or minimal reduction } 70-90 \% \\
\text { or minimal reduction } 75 \% \\
\text { or minimal reduction } 90 \% \\
\text { or minimal reduction } 70-80 \% \\
\text { or minimal reduction } 80 \%\end{array}$ \\
\hline
\end{tabular}

Household sewage from 13 towns and villages flows into the wastewater treatment plant, being Goleniów, Podańsko, Budno, Danowo, Białun, Łozienica, Krępsko, Zdżary, Łaniewo, Miękowo, Białun, Żółwia Błoć and Marszewo (Goleniów Industrial Park). Sewage is also delivered to the catchment point on the site of the sewage treatment plant by means of septic tanks from the area of the Goleniów Commune. The total number of inhabitants of the Goleniów agglomeration is 25,477 . The number of inhabitants connected to the sewage system is 23,845 . The percentage of sewerage in the Goleniów agglomeration is $93.6 \%$. Industrial sewage accounts for about $12.6 \%\left(700 \mathrm{~m}^{3} / \mathrm{d}\right)$ of the amount of sewage flowing into the treatment plant. The treated sewage is collected by the Ina River, to which the sewage is discharged through an open ditch. The outlet is located at $\mathrm{km} 13.8$ of the river. The Ina flows into the Odra River beyond the northern end of Lake Dąbie.

The average daily amount of sewage flowing into the treatment plant in 20092019 ranged from 4996.5 to $6029 \mathrm{~m}^{3} / \mathrm{d}$ (Fig. 2). In 2017, the highest average wastewater inflow to the treatment plant was recorded $\left(7,030.9 \mathrm{~m}^{3} / \mathrm{d}\right)$. This was caused by a high annual rainfall amounting to about $1000 \mathrm{~mm}$, while the average annual rainfall for the West Pomeranian Voivodeship is 490-770 mm [http://eregion.wzp.pl]. During rainy periods, the inflow of sewage to the treatment plant increases by about $30 \%$.

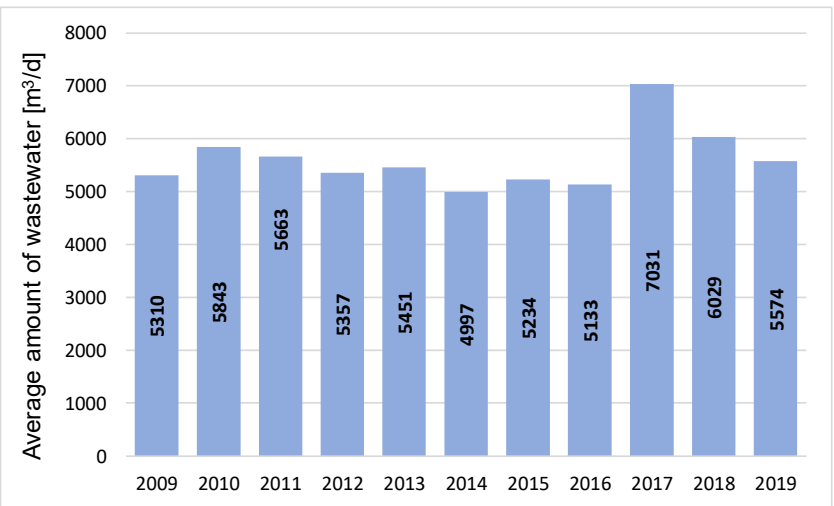

Fig. 2. Average amount of wastewater flowing into the treatment plant in 2009-2019 
Despite the significant expansion of the sewage network in the agglomeration, both in the residential and industrial zones, the average amount of sewage flowing into the treatment plant did not increase significantly. The reason for this was a continuous decrease in the amount of water consumed per 1 inhabitant and, consequently, in the amount of sewage produced.

\section{MODERNIZATION OF THE TECHNOLOGICAL SYSTEM}

Before modernization, the wastewater treatment plant operated using low-loaded activated sludge with biological nitrogen and phosphorus removal. Raw wastewater and leachate from the treatment plant facilities flowed into the pumping station And was then directed to the mechanical section, which consisted of two grates: a self-cleaning mechanical step grate and an emergency manual flat grate, and a two-zone vertical sand trap.

The wastewater, devoid of screenings and sand, flowed by gravity into two biooxyblocks working in parallel.

The single BIOOXYBLOCK reactor consisted of:

- biosorption chambers - hypoxic and anaerobic chamber,

- biostabilization chambers - oxygen chamber,

- secondary settling tank.

The load of activated sludge in the biostabilization chamber $\leq 0.04 \mathrm{~kg} \mathrm{BOD} 5 / \mathrm{kg}$ d.m.o. The processes taking place in the biological reactor included the oxidation of organic carbon compounds, oxidation of nitrogen compounds, and the synthesis of activated sludge biomass. Wastewater aeration in the Biooxyblock was carried out by means of aerators and blowers controlled as a function of the dissolved oxygen concentration in the chamber.

Then, the sewage was directed to the secondary settling tank with four sedimentation wells. From them, the sludge was recirculated to the biosorption chamber and discharged to the central pipe of the settling tank. In the central pipe, excess sludge was pre-thickened and directed to sedimentary lagoons, and then farmed. 


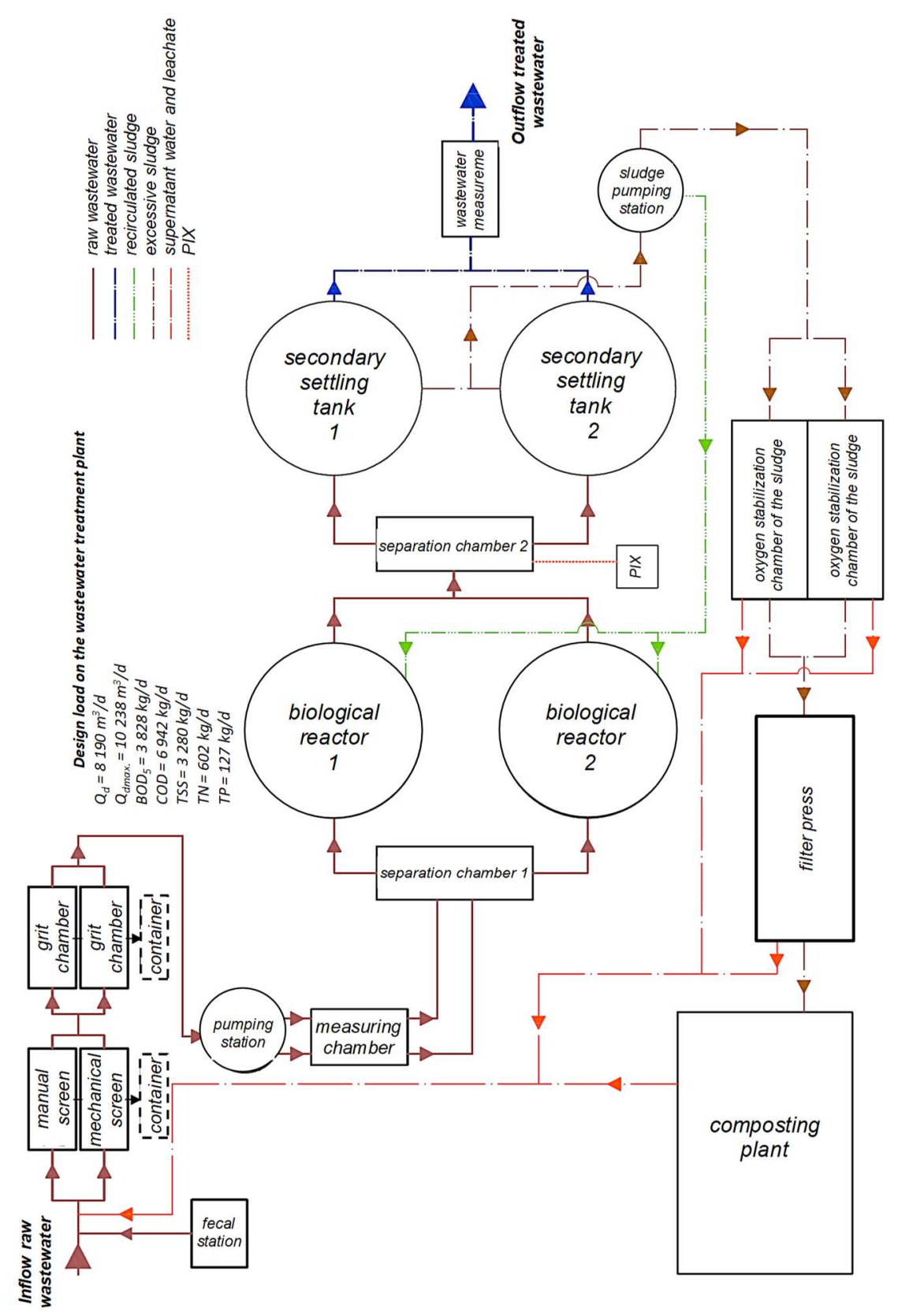

Fig. 3. Technological diagram of the wastewater treatment plant after modernization 
The expansion and modernization of the existing installation resulted from the need to adapt the treatment plant to accept a greater load of pollutants, obtain better parameters of treated sewage discharged to the receiver, the need to modernize the sludge management, and the poor technical condition of the equipment. Before the modernization of the treatment plant, a reduction in the efficiency of removing pollutants from wastewater had been observed.

During the modernization, the technological line of the wastewater treatment plant was expanded with new facilities: a grate building, an aerated sand trap, a sand separator, a mechanical sludge dewatering and hygienization station, an installation for chemical phosphorus precipitation, a sludge oxygen stabilization chamber, a sludge storage, a composting plant, an excess and return sludge pumping station, hall blowers, and secondary sedimentation tanks (Fig. 3). The capacity of the biological reactors was increased, in which the following zones were separated: predenitrification, anaerobic, denitrification, and nitrification. Chemical precipitation of phosphorus was introduced into the biological reactors. The method of aeration of nitrification chambers was also changed from surface aerators to fine bubble diffusers. Secondary settling tanks were also added as separate devices.

The reconstruction of the sewage sludge dewatering and hygienization station was to reduce the nuisance of the sewage treatment plant to the environment and allow for the lawful management of sewage sludge.

Due to the development of the technological system, the possibilities for loading the treatment with the pollutant load increased. The actual hydraulic load of the sewage treatment plant is approx. $5,680 \mathrm{~m}^{3} / \mathrm{d}$ and is lower than the projection. The comparison of the technological parameters of the wastewater treatment plant before and after the modernization is shown in Table 1.

Table 1. Design load of the wastewater treatment plant before and after modernization

\begin{tabular}{|c|c|c|}
\hline Parameter & $\begin{array}{c}\text { Design load on the } \\
\text { wastewater treatment plant }\end{array}$ & $\begin{array}{l}\text { Wastewater treatment plant } \\
\text { load after modernization }\end{array}$ \\
\hline $\mathrm{PE}$ & 25000 & 45000 \\
\hline $\mathrm{Q}_{\mathrm{d}\left[\mathrm{m}^{3} / \mathrm{d}\right]}$ & 9388 & 8190 \\
\hline Load $\left[\mathrm{kgBOD}_{5} / \mathrm{d}\right]$ & 2136 & 3828 \\
\hline Total nitrogen $[\mathrm{kg} / \mathrm{d}]$ & 284 & 602 \\
\hline Total phosphorus $[\mathrm{kg} / \mathrm{d}]$ & 27 & 127 \\
\hline \multicolumn{3}{|c|}{ Load to be removed in the wastewater treatment process } \\
\hline$[\mathrm{kg} / \mathrm{d}]$ & 1948 & 3624 \\
\hline$[\mathrm{kg} / \mathrm{d}]$ & - & 2993 \\
\hline$[\mathrm{kg} / \mathrm{d}]$ & 1996 & 3280 \\
\hline Total nitrogen $[\mathrm{kg} / \mathrm{d}]$ & 77 & 479 \\
\hline Total phosphorus $[\mathrm{kg} / \mathrm{d}]$ & - & 110 \\
\hline
\end{tabular}




\section{RESULTS AND DISCUSSION}

In the analyzed period, the average wastewater inflow to the treatment plant was at the level of $5000-6000 \mathrm{~m}^{3} / \mathrm{d}$. Over the past 11 years, there has been an increase in the concentration of pollutants in the wastewater flowing into the treatment plant. Table 2 presents the loads of pollutants in raw sewage in 2009-2019. The presented data indicate an increase in pollutant loads, especially $\mathrm{BOD}_{5}, \mathrm{COD}$, and total suspended solids.

Table 2. Average loads of pollutants flowing into the treatment plant in 2009-2019

\begin{tabular}{|c|c|c|c|c|c|}
\hline \multirow{2}{*}{ Year } & \multicolumn{5}{|c|}{ Pollution load [kg/d] } \\
\cline { 2 - 6 } & $\boldsymbol{B O D}_{\mathbf{5}}$ & COD & TSS & $\boldsymbol{T N}$ & $\boldsymbol{T P}$ \\
\hline $\mathbf{2 0 0 9}$ & 1259 & 3587 & 1344 & 331 & 81 \\
\hline $\mathbf{2 0 1 0}$ & 2076 & 4500 & 1864 & 407 & 82 \\
\hline $\mathbf{2 0 1 1}$ & 2442 & 4517 & 1643 & 373 & 60 \\
\hline $\mathbf{2 0 1 2}$ & 2690 & 4404 & 1854 & 354 & 69 \\
\hline $\mathbf{2 0 1 3}$ & 1699 & 4156 & 1576 & 327 & 52 \\
\hline $\mathbf{2 0 1 4}$ & 1825 & 4448 & 1521 & 307 & 50 \\
\hline $\mathbf{2 0 1 5}$ & 2487 & 5879 & 1861 & 386 & 79 \\
\hline $\mathbf{2 0 1 6}$ & 2455 & 5467 & 1911 & 362 & 75 \\
\hline $\mathbf{2 0 1 7}$ & 2598 & 5353 & 2639 & 373 & 90 \\
\hline $\mathbf{2 0 1 8}$ & 2249 & 5950 & 2339 & 354 & 89 \\
\hline $\mathbf{2 0 1 9}$ & 2154 & 5493 & 1998 & 386 & 72 \\
\hline
\end{tabular}

Due to the modernization of the wastewater treatment plant, which took place from May 2010 to December 2011, this period was not included in the analysis of the effectiveness of the treatment plant's operation.

Before the modernization of the technological system of the treatment plant, $\mathrm{BOD}_{5}$ in raw sewage was in the range of $163 \div 420 \mathrm{gO}_{2} / \mathrm{m}^{3}$ (average: 342.3 $\mathrm{gO}_{2} / \mathrm{m}^{3}$ ), and after modernization $154 \div 780 \mathrm{gO}_{2} / \mathrm{m}^{3}$ (average: $407.9 \mathrm{gO}_{2} / \mathrm{m}^{3}$ ). 


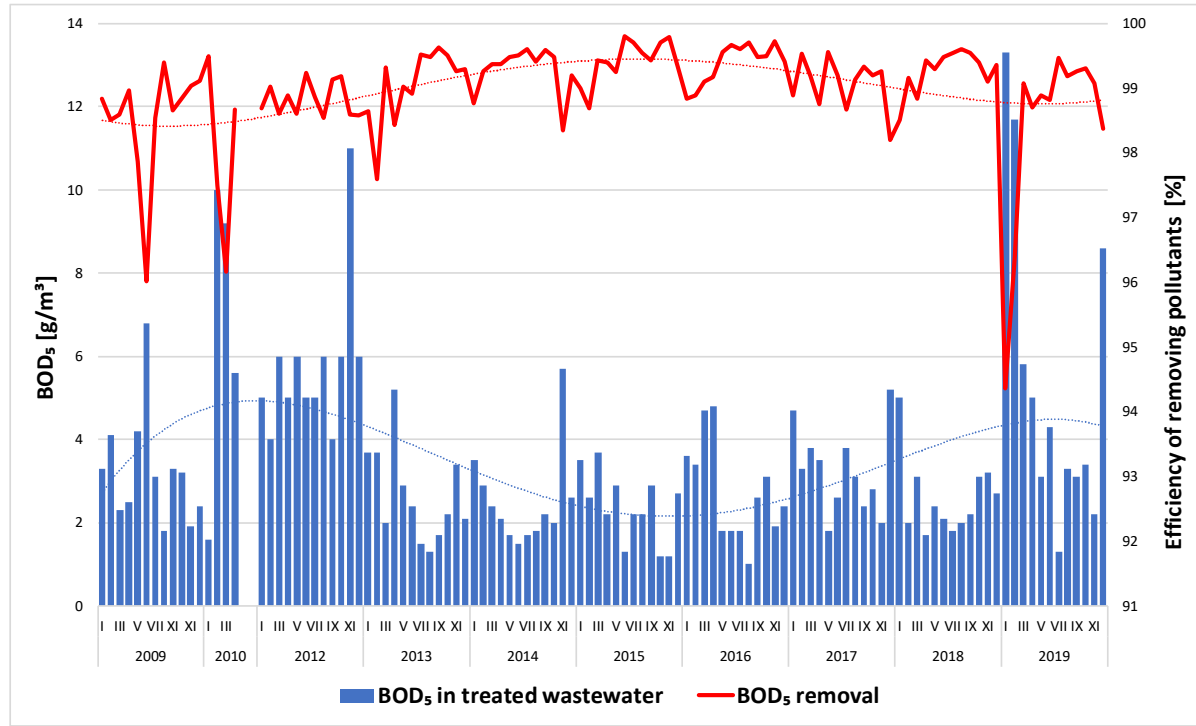

Fig. 4. $\mathrm{BOD}_{5}$ in treated wastewater and removal efficiency

In treated sewage, $\mathrm{BOD}_{5}$ reached values of 1.6 to $10.0 \mathrm{gO}_{2} / \mathrm{m}^{3}$ (average: 4.1 $\mathrm{gO}_{2} / \mathrm{m}^{3}$ ) before the modernization, and from 1.0 to $13.3 \mathrm{gO}_{2} / \mathrm{m}^{3}$ (average: 3.4 $\mathrm{gO}_{2} / \mathrm{m}^{3}$ ) after expanding the technological system. The efficiency of $\mathrm{BOD}_{5}$ removal from wastewater after the modernization of the technological system was within the range of $94.4 \div 99.8 \%$. Despite the increase in $\mathrm{BOD}_{5}$ loads flowing into the treatment plant, the $\mathrm{BOD}_{5}$ values in the wastewater discharged to the receiving body were lower (Fig. 4).

The values of the COD index in raw sewage, in the period before the modernization of the system, ranged from 495 to $896 \mathrm{gO}_{2} / \mathrm{m}^{3}$. The average value of COD in raw sewage was $742.7 \mathrm{gO}_{2} / \mathrm{m}^{3}$. In the analyzed period, the average daily load of the sewage treatment plant with the COD load ranged from 2593 to $5032 \mathrm{~kg} / \mathrm{d}$. COD in raw sewage after modernization was in the range of $431 \div$ $1059 \mathrm{gO}_{2} / \mathrm{m}^{3}$ (average: $922 \mathrm{gO}_{2} / \mathrm{m}^{3}$ ). The average daily load of the sewage treatment plant with the COD load ranged from 2,664 to 9,770 $\mathrm{kg} / \mathrm{d}$ (average: $5144 \mathrm{~kg} / \mathrm{d}$ ). In the analyzed period, the COD load increased significantly, with the amount of incoming sewage being almost unchanged. 


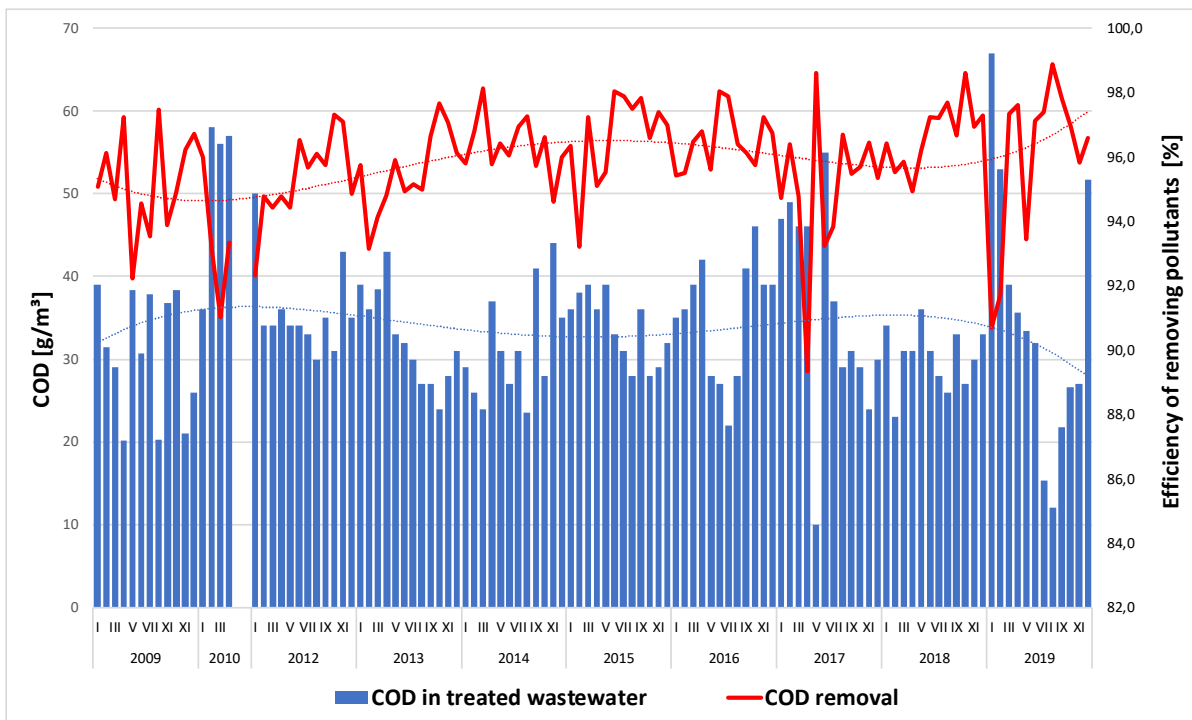

Fig. 5. COD in treated wastewater and removal efficiency

In the sewage treated before the modernization of the treatment plant, COD ranged from 20.2 to $58 \mathrm{gO}_{2} / \mathrm{m}^{3}$ (average: $36 \mathrm{gO}_{2} / \mathrm{m}^{3}$ ). The COD load discharged to the receiver was $94 \div 407 \mathrm{~kg} / \mathrm{d}$. The efficiency of COD removal from the wastewater was in the range of $91.0 \div 97.5 \%$. After the extension of the facility was completed, COD in the treated sewage ranged from 10 to $67 \mathrm{gO}_{2} / \mathrm{m}^{3}$ (average: $33.7 \mathrm{gO}_{2} / \mathrm{m}^{3}$ ). The COD load discharged to the receiver was in the range of $94 \div 407 \mathrm{~kg} / \mathrm{d}$. The efficiency of COD reduction in the wastewater ranged from $89.3 \div 98.9 \%$ (Fig. 5 ).

In the analyzed period, the amount of total suspended solids in the incoming sewage remained relatively constant, and the total suspended solids load changes proportionally to the amount of sewage. The concentration of total suspended solids in raw sewage before the extension of the facility was in the range of $126 \div 350 \mathrm{~g} / \mathrm{m}^{3}$.

The average daily load of total suspended solids flowing into the treatment plant in the analyzed period was between 864 and $1907 \mathrm{~kg} / \mathrm{d}$. In the period after the modernization, the amount of total suspended solids in raw sewage ranged from $107 \div 1012 \mathrm{~g} / \mathrm{m}^{3}$, and the daily load flowing into the treatment plant, from 669 to $6619 \mathrm{~kg} / \mathrm{d}$. 


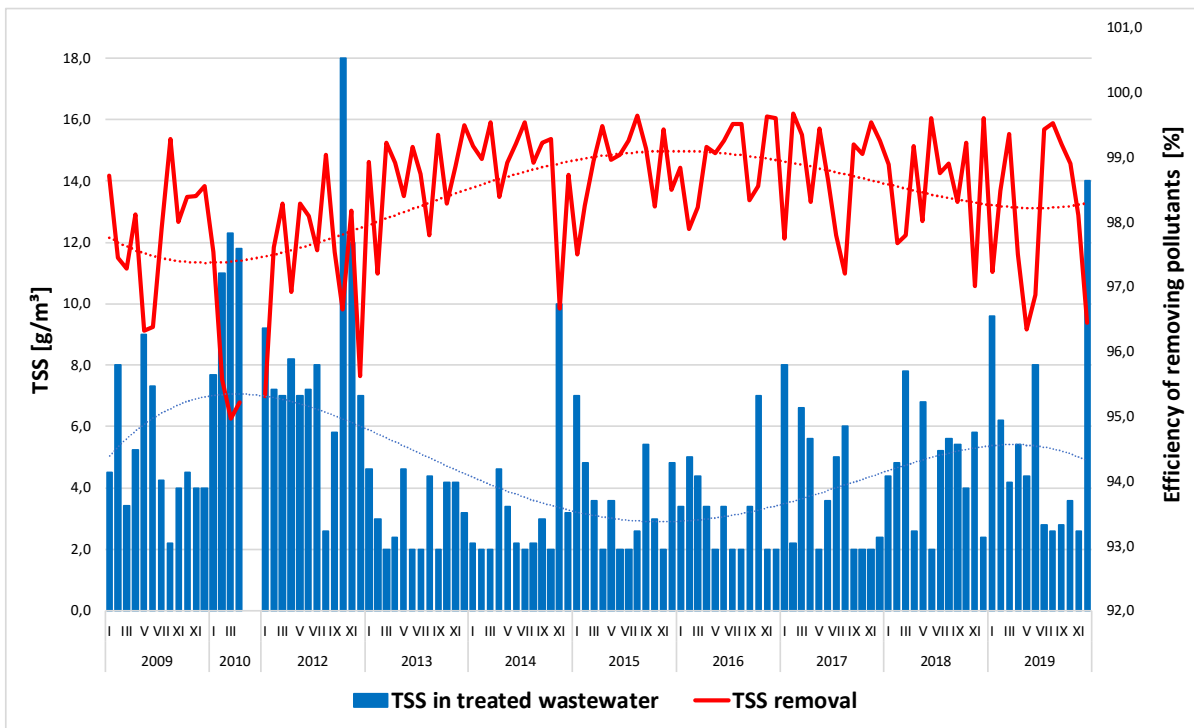

Fig. 6. Total suspension in treated wastewater and removal efficiency

The total suspended solids content in the sewage treated before the modernization was in the range of $2.2 \div 12.3 \mathrm{~g} / \mathrm{m}^{3}$ (average: $13.4 \mathrm{~g} / \mathrm{m}^{3}$ ), and the load discharged to the receiver was in the range of $10 \div 89 \mathrm{~kg} / \mathrm{d}$. The efficiency of total suspended solids removal in the sewage ranged from $95.0 \div 99.3 \%$. After the modernization works were completed, the total suspended solids concentration in the treated sewage was in the range of $2.0 \div 18 \mathrm{~g} / \mathrm{m}^{3}$ (average: $4.5 \mathrm{~g} / \mathrm{m}^{3}$ ), and the effectiveness of the indicator removal from the sewage was in the range of $95.3 \div 99.7 \%$. In the years 2012-2019, the total suspended solids load discharged to the environment was in the range of $9 \div 97 \mathrm{~kg} / \mathrm{d}$ (Fig. 6).

Over the years, the requirements for the discharge of nutrients to the receiver have become stricter. The total permissible amount of nitrogen in treated wastewater was reduced from $20 \mathrm{~g} / \mathrm{m}^{3}$ to $15 \mathrm{~g} / \mathrm{m}^{3}$ and total phosphorus from $5 \mathrm{~g} / \mathrm{m}^{3}$ to $2 \mathrm{~g} / \mathrm{m}^{3}$. The amount of total nitrogen in raw sewage before modernization was $40.3 \div 90.2$ $\mathrm{g} / \mathrm{m}^{3}$ (average: $66.3 \mathrm{~g} / \mathrm{m}^{3}$ ). The average daily load of total nitrogen was in the range of $201 \div 492 \mathrm{~kg} / \mathrm{d}$. The total nitrogen load on the treatment plant exceeded the design value $-284 \mathrm{~kg} / \mathrm{d}$. After the modernization of the treatment plant, the raw sewage contained from $34 \mathrm{~g} / \mathrm{m}^{3}$ to $122 \mathrm{~g} / \mathrm{m}^{3}$ (average: $64.0 \mathrm{~g} / \mathrm{m}^{3}$ ) of total nitrogen. The average daily load of the wastewater treatment plant with the load of total nitrogen in the years $2012-2019$ ranged from $207 \div 581 \mathrm{~kg} / \mathrm{d}$. The total nitrogen load flowing into the treatment plant decreased despite the expansion of the sanitary sewage system. 


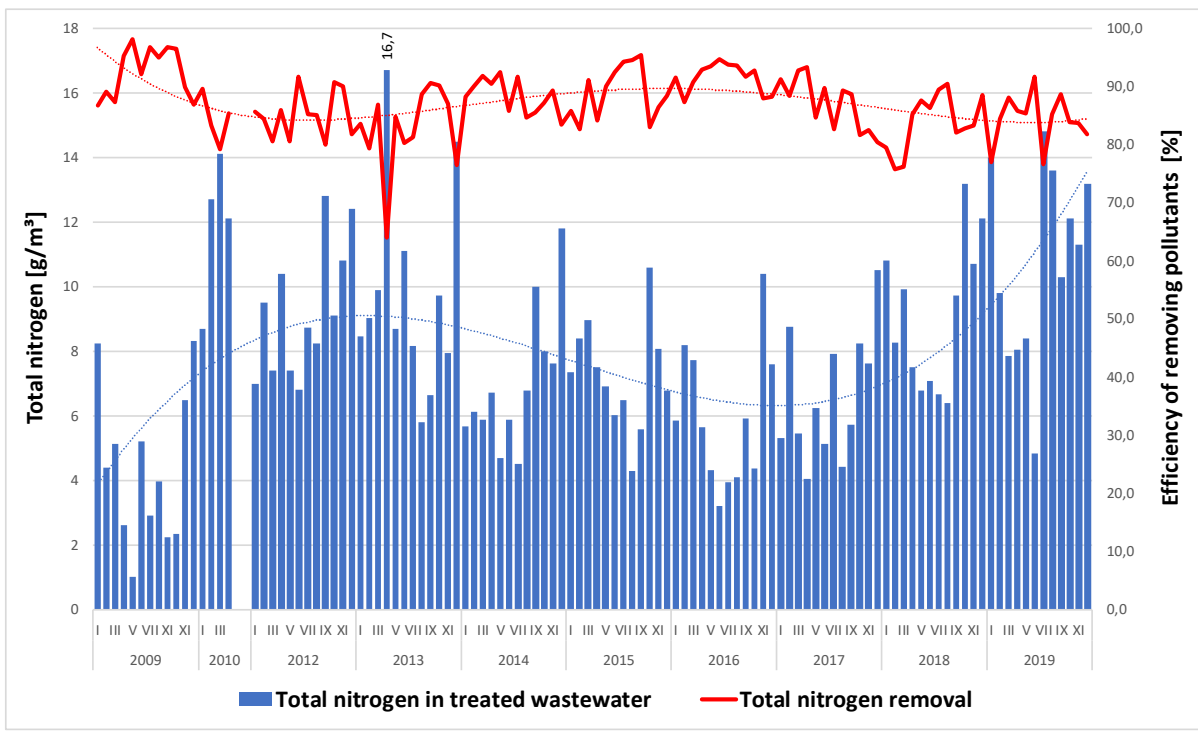

Fig. 7. Total nitrogen in treated wastewater and removal efficiency

The total amount of nitrogen in the sewage treated before the expansion of the technological system was in the range of $1.0 \div 14.1 \mathrm{~g} / \mathrm{m}^{3}$ (average value: $6.3 \mathrm{~g} / \mathrm{m}^{3}$ ). Total nitrogen load discharged with the treated sewage amounted to $6 \div 103 \mathrm{~kg} / \mathrm{d}$ of total nitrogen. The efficiency of total nitrogen removal from the wastewater ranged from $79.1 \%$ to $98.2 \%$. After the expansion of the treatment plant was completed, the average total nitrogen concentration in the treated sewage ranged between $3.2 \div 14.8 \mathrm{~g} / \mathrm{m}^{3}$ (average: $8.2 \mathrm{~g} / \mathrm{m}^{3}$ ). The total nitrogen load discharged to the receiver was within the range of $16 \div 98 \mathrm{~kg} / \mathrm{d}$. The efficiency of nitrogen removal from wastewater was within the range of $64.1 \div 95.4 \%$ (Fig. 7).

The concentration of total phosphorus in the raw sewage flowing into the treatment plant in the period before modernization was $10.7 \div 33.9 \mathrm{~g} / \mathrm{m}^{3}$ (average: $14.4 \mathrm{~g} / \mathrm{m}^{3}$ ). The average daily load of the sewage treatment plant with the phosphorus load was in the range of $54 \div 187 \mathrm{~kg} / \mathrm{d}$. The plant's total phosphorus load significantly exceeded the design value of $27 \mathrm{~kg} / \mathrm{d}$. In the years $2012-2019$, the amount of total phosphorus in the raw sewage ranged from $6.1 \mathrm{~g} / \mathrm{m}^{3}-35.4$ $\mathrm{g} / \mathrm{m}^{3}$ (average: $12.8 \mathrm{~g} / \mathrm{m}^{3}$ ). The average daily load of the sewage treatment plant with the load of total phosphorus at that time was in the range of $33 \div 205 \mathrm{~kg} / \mathrm{d}$. 


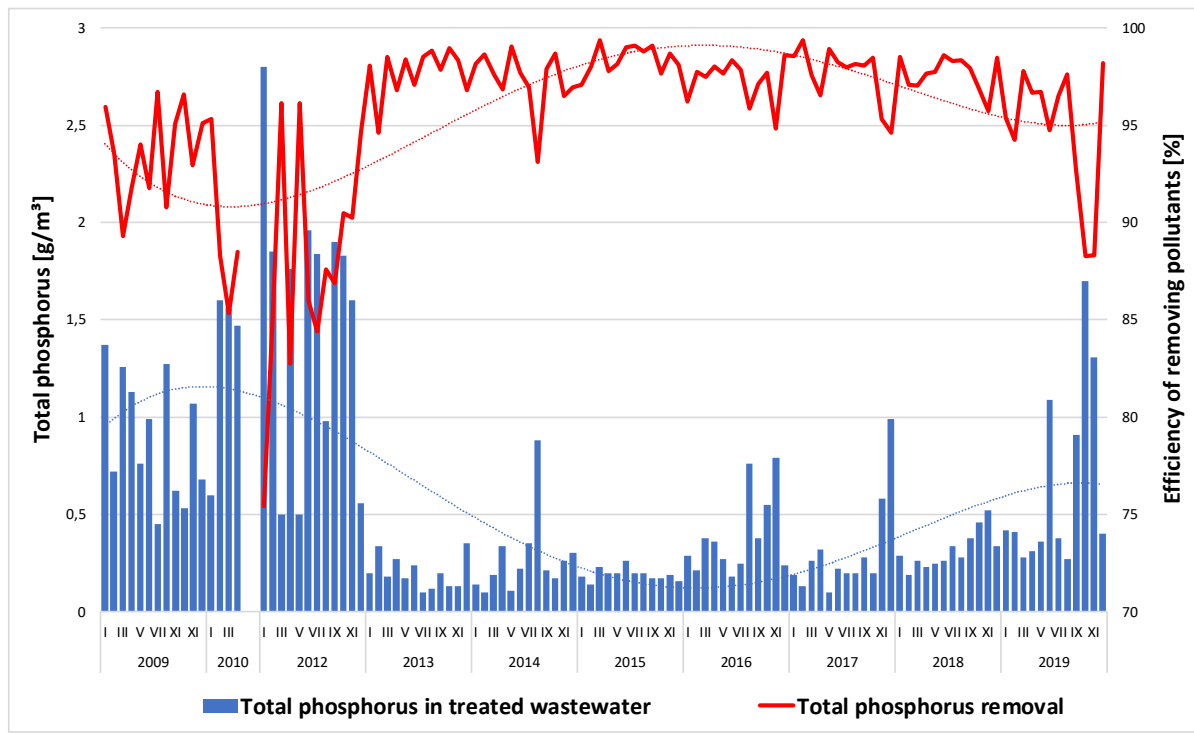

Fig. 8. Total phosphorus in treated wastewater and removal efficiency

The sewage treated before the modernization of the treatment plant contained 0.45 to $1.6 \mathrm{~g} / \mathrm{m}^{3}$. The average concentration of total phosphorus in the treated sewage was $-1.4 \mathrm{~g} / \mathrm{m}^{3}$. Between 2 to $9 \mathrm{~kg} / \mathrm{d}$ of total phosphorus load were discharged with the treated sewage. The total phosphorus removal efficiency in the analyzed period was in the range of $85.4 \div 96.7 \%$. The introduction of chemical phosphorus precipitation into the technological system significantly lowered the concentration of total phosphorus in the treated sewage after modernization. The concentration of total phosphorus in treated wastewater was in the range of $0.10 \div 2.8 \mathrm{~g} / \mathrm{m}^{3}$ (average: $0.5 \mathrm{~g} / \mathrm{m}^{3}$ ). The permissible value of the indicator according to the water law permit was $<2 \mathrm{~g} / \mathrm{m}^{3}$. The total phosphorus removal efficiency in this period was in the range of 75.4-99.4\% (Fig. 8).

After the modernization of the wastewater treatment plant in Goleniów, the efficiency of removing pollutants contained in the sewage increased (Table 2). The exception is total nitrogen, for which the removal efficiency decreased by approx. $4 \%$. It should be noted that the wastewater treatment plant before modernization showed high efficiency of phosphorus removal by biological dephosphatation, but the introduction of chemical phosphorus precipitation into the technological system ensured stability and even higher efficiency of the process. 
Table 2. Effectiveness of removing pollutants in the wastewater treatment plant before and after modernization

\begin{tabular}{|l|c|c|}
\hline Parameter & $\begin{array}{c}\text { \% removal before } \\
\text { modernization }\end{array}$ & $\begin{array}{c}\text { \% removal after } \\
\text { modernization }\end{array}$ \\
\hline$B O D_{5}$ & 98.4 & 99.1 \\
\hline$C O D$ & 94.8 & 96.0 \\
\hline$T S S$ & 97.4 & 98.5 \\
\hline Total nitrogen & 90.5 & 86.5 \\
\hline Total phosphorus & 92.6 & 96.1 \\
\hline
\end{tabular}

\section{CONCLUSION}

The wastewater treatment plant in Goleniów, both before and after the modernization of the technological system, was characterized by high efficiency in removing pollutants. There has been a significant increase in pollutant loads flowing into the treatment plant, e.g., $\mathrm{BOD}_{5}, \mathrm{COD}$, and periodic total suspended solids. The modernization prepared the treatment plant for removing larger loads of pollutants flowing into the treatment plant during the day. Before modernization, total phosphorus was removed only biologically so, during the modernization, chemical precipitation of phosphorus was introduced, which increased the efficiency of its removal. The average concentration of phosphorus in the sewage treated before the modernization was $-1.4 \mathrm{~g} / \mathrm{m}^{3}$, and after the modernization $-0.5 \mathrm{~g} / \mathrm{m}^{3}$.

The effectiveness of wastewater treatment after the modernization of the system showed the effectiveness of the applied wastewater treatment processes and the correct selection of the technological line. The efficiency of removing pollutants after modernization was in the range of: $\mathrm{BOD}_{5}-94.4 \div 99.8 \%$, COD $-89.3 \div 98.9$ $\%$, total suspended solids $-95.3 \div 99.7 \%$, total nitrogen $-64.1 \div 95.4 \%$, total phosphorus - $75.4 \div 99.4 \%$.

\section{REFERENCES}

1. Bugajski, P, Chmielowski, K and Kaczor, G 2016. Influence of the size of flow of rainwater on the composition of raw wastewater in small sewer system. Acta Sci. Pol. Formatio Circumiectus 15, 3-11.

2. Jaromin-Gleń, K et al. 2015. Effect of "Hajdow" wastewater treatment plant modernization on wastewater purification process. Ecol. Chem. Eng. A. 22(3), 297-311.

3. Lenart-Boroń, A, Bojarczuk, A , Jelonkiewicz, $Ł$ and Żelazny, M 2019. The effect of a Sewage Treatment Plant modernization on changes in the 
microbiological and physicochemical quality of water in the receiver. Archives of Environmental Protection Vol. 45 no. 2, 37-49.

4. Młyński, D, Bugajski, P and Młyńska, A 2019. Application of the Mathematical Simulation Methods for the Assessment of the Wastewater Treatment Plant Operation Work Reliability. Water 11, 873.

5. Młyński, D, Chmielowski, K and Młyńska, A 2016. Analysis of hydraulic load of a wastewater treatment plant in Jasło. J. Water Land Dev. 28, 61-67.

6. Nowak, J, Chmielowski, K, Chmielowska, B and Bedla, D 2016. The efficiency of pollutant elimination in the Dobra treatment plant. Infrastruct. Ecol. Rural Areas 3, 737-747.

7. Płuciennik-Koropczuk, E and Myszograj S. 2019. New Approach in COD Fractionation Methods. Water 11(7), 1484.

8. Regulation of the Minister of Maritime Economy and Inland Navigation of 12 July 2019 on substances particularly harmful to the aquatic environment and the conditions to be met when discharging sewage into waters or soil, as well as when discharging rainwater or meltwater into waters or into devices aquatic, Dz.U.2019 poz.1311.

Editor received the manuscript: 21.06.2021 